\title{
A KÜLÖN ÉLŐ APÁK KAPCSOLATTARTÁSI SZOKÁSAI MAGYARORSZÁGON
}

\section{PATTERNS OF NON-RESIDENT FATHERS' CONTACTS WITH THEIR CHILDREN IN HUNGARY}

\author{
Szalma Ivett ${ }^{1}$, Rékai Krisztina ${ }^{2}$ \\ ${ }^{1}$ PhD, Társadalomtudományi Kutatóközpont, Magyar Tudományos Akadémia Kiváló Kutatóhely, Budapest; \\ Budapesti Corvinus Egyetem, Budapest \\ ivett.szalma@uni-corvinus.hu \\ 2 BA-hallgató, University of Warwick, Coventry, Egyesült Királyság \\ Krisztina.Rekai@warwick.ac.uk
}

\begin{abstract}
ÖSSZEFOGLALÁS
Jelen tanulmány célja, hogy bemutassa a külön élő apa és a gyermeke közötti kapcsolattartási mintázatokat Magyarországon. A kutatási kérdésünk, hogy milyen tényezők befolyásolják a kapcsolattartás gyakoriságát a külön élő apák és gyermekeik között. Ehhez kvalitatív és kvantitatív adatok elemzésére is támaszkodunk. A vizsgálatunk eredménye, hogy a külön élő apák jelenlegi családi helyzete mellett a gyermek életkora is fontos tényező, bár a gyermek életkora nem lineáris, hanem fordított $U$ alakú összefüggést mutat. Az apák az óvodás és kamaszkor között tartják legintenzívebben a kapcsolatot a külön élő gyermekeikkel. Emellett annak volt még szignifikáns hatása, hogy vajon a külön élő szülő és a gyermek milyen messze lakik egymástól.
\end{abstract}

\section{ABSTRACT}

The purpose of this study is to present the patterns of contacts between non-resident fathers and their children in Hungary. Our research question is what factors can influence the frequency of personal contacts between non-resident fathers and their children. We rely on both qualitative and quantitative data analysis. The result of our study is that besides the current family status of the non-resident fathers, the age of the child is also an important factor. Although the age of the child does not influence the frequency of the contact linearly, it shows an inverse $\mathrm{U}$-shaped relationship. Non-resident fathers hold the most frequent contact with their children who are older than three and younger than adolescence. In addition, there was a significant effect of the distance between the non-resident father and their children's place(s) of living.

Kulcsszavak: külön élő apák, személyes kapcsolattartás, interjúk, Életünk fordulópontjai adatbázis

Keyworlds: non-resident fatherhood, personal contact, interviews, Turning Points of Our Lives database 


\section{BEVEZETÉS}

Egyre elterjedtebbé válnak azok a kutatások, ahol a külön élő apa kapcsolattartását vizsgálják a gyermekeivel. Az USA-ban már az 1990-es évek elején elkezdték vizsgálni a témát, reflektálva a 20. század második felére jellemző magas válási arányszámokra (lásd például Seltzer, 1991). Az észak- és nyugat-európai országokban azonban csak a 2000-es évektől kezdték el intenzívebben vizsgálni a külön élő szülők (általában az apák) és gyermekeik közötti kapcsolattartást. Miközben a posztszocialista régióban csak a legutóbbi években találkozhatunk ilyen jellegü kutatásokkal. Litvániában például Maslauskaite és Tereškinas (2020) vizsgálta, hogy milyen a kapcsolattartással való elégedettség a külön élő apa és gyermeke között, Magyarországon pedig Makay és Spéder (2018) készített leíró elemzést a külön élő apák kapcsolattartásáról kvantitatív adatokon, valamint Szalma és Rékai (2019) végzett interjús elemzéseket a szülöi felügyeleti jog, a kapcsolattartás és a tartásdíjfizetés kérdéséről. Jelen tanulmány célja, hogy mindkét adatforrás felhasználásával, azaz kvantitatív és kvalitatív adatokon megvizsgálja, hogy Magyarországon a külön élő apák miként tartják a kapcsolatot a gyermekeikkel. Ehhez felhasználjuk az Életünk fordulópontjai adatbázis 2012-2013-as adatait, valamint 2019. április és június között készített huszonöt félig strukturált interjút, amelyet nyolc szülöpár mindkét tagjával - amikor mind az anya, mind az apa részt vett a vizsgálatban, valamint öt külön élö apával és négy, gyermekét egyedül nevelő anyával készítettünk. Az anyák bevonására a vizsgálatban azért került sor, hogy a „másik oldal” nézőpontjai is megjelenhessenek az elemzésben.

\section{KORÁBBI IRODALMAK ÁTTEKINTÉSE}

A korábbi kutatások azt találták, hogy számos szociodemográfiai tényező befolyásolhatja a külön élő apák és gyermekeik közötti kapcsolattartást. A külön élő apák jövedelmi helyzete, iskolai végzettsége, munkaerőpiaci helyzete és az életkora is kapcsolatban állhat azzal, hogy milyen gyakran találkoznak a velük nem egy háztartásban élő gyermekeikkel (például Goldberg-Carlson, 2015; Skevik, 2006). A kapcsolattartás általában anyagi ráfordítást igényel. Például utazási költségek merülhetnek fel, amennyiben az apa és a gyermeke különböző településen élnek, amelyek általában az apát terhelhetik. Szintén költségesek lehetnek a találkozásokkor megszervezett közös programok. Így a magasabb jövedelmi helyzetü és jobb munkapiaci helyzetủ apák inkább tartják a kapcsolatot a külön élő gyermekeikkel (Goldberg-Carlson, 2015; Skevik, 2006).

Az anyagi helyzet mellett a külön élő apa iskolai végzettsége is befolyásolhatja, hogy miként vesz részt a gyermeke életében. A korábbi kutatások azt találták, hogy a magas iskolai végzettség pozitív kapcsolatban áll a személyes találkozások 
gyakoriságával (Goldberg-Clarson, 2015). Ennek egyik lehetséges magyarázata, hogy a magas iskolai végzettséggel rendelkező apák sokszínűbbnek érzik apai identitásukat, így az anyagi háttér biztosítása mellett más területeken is igyekeznek részt venni gyermekeik életében, például közös programok megszervezésével és érzelmi támasz nyújtásával (Goldberg, 2015; Spéder, 2011).

Az életkor szerint is találtak különbséget a külön élő apa és gyermek közötti kapcsolattartásban: fiatalabb külön élő apák kevésbé vesznek részt a gyermekeik életében, mint idősebb társaik (Goldberg-Clarson, 2015). Ennek hátterében az is állhat, hogy akik fiatalon (tizenévesen vagy húszas éveik elején) váltak apává azoknál kevésbé volt tervezett a gyermekvállalás. Laura Duberstein Lindberg és szerzőtársai (2017) 2002 és 2010 közötti amerikai adatokon kimutatták, hogy szoros összefüggés van aközött, hogy tervezett vagy nem tervezett volt a gyermekvállalás, és hogy a külön élő apák milyen gyakorisággal tartják a kapcsolatot velük.

Továbbá az apa új családi állapota is befolyásolhatja a kapcsolattartást a külön élő gyermekével, mivel az új kapcsolat gyakran jelenthet új elköteleződést és több időbeli ráfordítást az apa számára, melyek a gyermekkel való kapcsolattartás rovására történhetnek (Meggiolaro-Ongaro, 2014; Murinkó-Szalma, 2016). Amennyiben az új partnernek az elözö kapcsolatából gyermeke származik, az még összetettebb családi formát eredményezhet - különösen abban az esetben, ha az új partner, a gyermeke és a külön élő apa egy háztartásban élnek. Ebben az esetben nemcsak az új partnerrel való időtöltés, hanem a háztartásban élő gyermekre fordított idő is akadályozhatja a külön élő apa és gyermeke közötti kapcsolatot.

A korábbi kutatások arra is rávilágítottak, hogy a külön élő apa szociodemográfiai helyzete mellett a gyermek életkora és neme is szignifikánsan befolyásolhatja a kapcsolattartás gyakoriságát (Seltzer, 1991; Lindberg et al., 2017). Ez a jelenség azzal magyarázható, hogy az apák általában egyszerűbben találják meg a közös hangot az idősebb gyerekekkel, és nagyobb valószínűséggel látogatják rendszeresen a fiúgyermeküket.

A külön élö apa és gyermek szociodemográfiai helyzete mellett a korábbi kutatások azt találták, hogy minél messzebb él az apa a gyermekétől, annál ritkábban látogatja (Manning et al., 2003; Cheadle et al., 2010; Makay-Spéder, 2018). Továbbá minél több idő telik el az apa és gyermeke különélése óta, annál ritkábban látogatják a külön élő apák a gyermekeiket.

\section{EREDMÉNYEK}

\section{A kvantitatív kutatás eredményei}

Elöször az Életünk fordulópontjai adatbázis - mely a nemzetközi Turning Points of the Life Course Panel Survey része - negyedik hullámának (2012-2013-ban kérdezték le) adatain végzett leíró elemzések eredményeit mutatjuk be. Összesen 
8103 válaszadó töltötte ki a kérdőívet. A válaszadók között 165 olyan apa volt, akinek tizenkilenc év alatti külön élő gyermeke volt az adatfelvételkor. Ha egy apának több ilyen gyermeke is volt, akkor a legfiatalabbra vonatkozó válaszait elemeztük.

A kérdőívben két kérdés szerepelt a külön élő gyermekkel való kapcsolattartásról, ezeket külön-külön megvizsgáljuk leíró statisztikákkal, illetve lineáris regressziót is futtatunk annak feltárására, hogy milyen tényezők befolyásolják a személyes találkozások gyakoriságát a külön élő apa és gyermeke között Magyarországon.

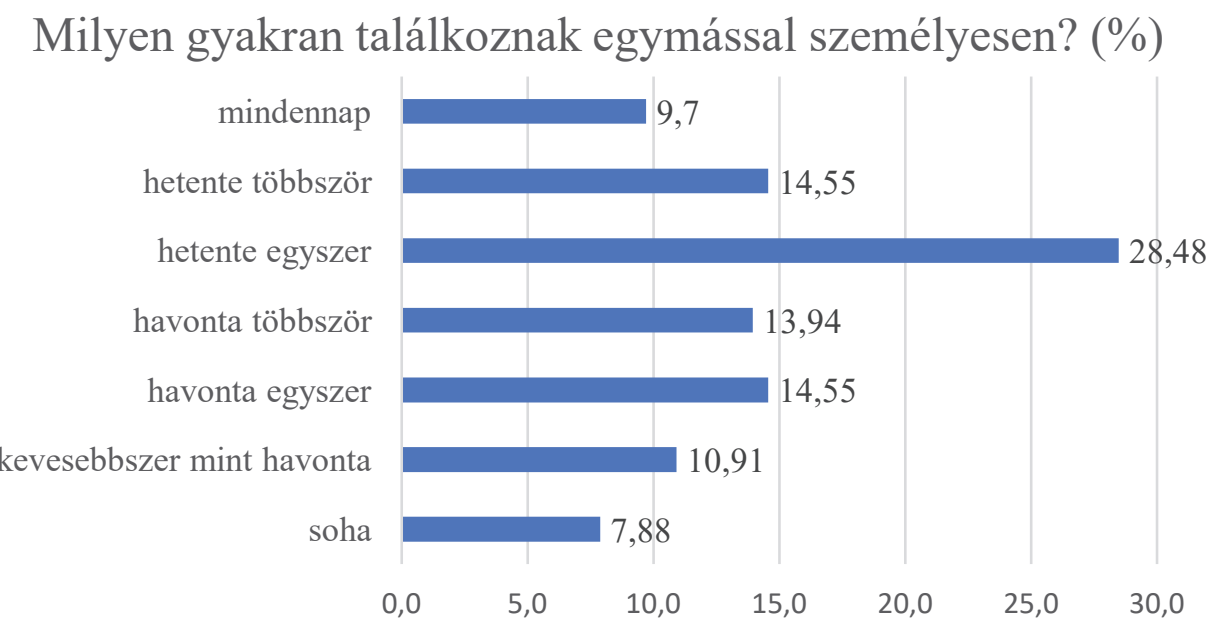

1. ábra. Milyen gyakran találkozik személyesen a külön élő apa a gyermekével (Életünk fordulópontjai adatbázis 4. hullám, $\mathrm{N}=165$ )

Az 1. ábrán látható, hogy a leggyakrabban előforduló mintázat, amikor az apák hetente egyszer találkoznak külön élő gyermekeikkel (28,5\%). Ezt követően azok vannak a legtöbben, akik havonta egyszer (14,6\%), illetve hetente többször $(14,6 \%)$ is találkoznak a külön élö, tizenkilenc év alatti gyermekeikkel. A külön élő apák mintegy 10\%-a mindennapi találkozásról számolt be, miközben körülbelül 8\%-uk mondta azt, hogy sohasem találkozik a gyermekével.

Lineáris regressziót végeztünk, hogy feltárjuk, miként befolyásolják a korábbi vizsgálatokban bevont szociodemográfiai változók a külön élő apa kapcsolattartását a gyermekével hazánkban. Az első táblázat összefoglalja az eredményeket.

A lineáris regresszió alapján azt állapíthatjuk meg, hogy az apa jelenlegi családi helyzete befolyásolja a kapcsolattartást. Ha az apa új együttélő kapcsolatot alakított ki, amelyben kiskorú gyermek is él a háztartásában, akkor az apák szig- 
1. táblázat. Milyen gyakran találkozik a külön élő apa a gyermekével?

Lineáris regresszió eredménye

\begin{tabular}{|c|c|c|c|}
\hline & Változók & $\begin{array}{l}\text { 1. modell: csak } \\
\text { szociodemográfiai } \\
\text { változók bevonása }\end{array}$ & $\begin{array}{l}\text { 2. modell: szociodemográfiai } \\
\text { változók + a különélés óta } \\
\text { eltelt idő, valamint azonos } \\
\text { településen él-e a külön élő apa } \\
\text { és gyermeke változók bevonása }\end{array}$ \\
\hline \multirow{4}{*}{$\begin{array}{l}\text { Külön élő } \\
\text { apa szocio- } \\
\text { demográfiai } \\
\text { helyzete }\end{array}$} & Életkor & Nincs szignifikáns hatás & Nincs szignifikáns hatás \\
\hline & $\begin{array}{l}\text { Iskolai } \\
\text { végzettség }\end{array}$ & Nincs szignifikáns hatás & Nincs szignifikáns hatás \\
\hline & $\begin{array}{l}\text { Munkaerő- } \\
\text { piaci helyzet }\end{array}$ & Nincs szignifikáns hatás & Nincs szignifikáns hatás \\
\hline & $\begin{array}{l}\text { Jelenlegi } \\
\text { családi } \\
\text { helyzet }\end{array}$ & $\begin{array}{l}\text { Van szignifikáns hatás: } \\
\text { Ha az apa új párkapcso- } \\
\text { latban él, és van kiskorú } \\
\text { gyermek a háztartásban, } \\
\text { akkor ritkábban találkozik } \\
\text { a külön éló gyermekével }\end{array}$ & Nincs szignifikáns hatás \\
\hline \multirow{2}{*}{$\begin{array}{l}\text { A vizsgált } \\
\text { gyermek } \\
\text { szocio- } \\
\text { demográfiai } \\
\text { adatai }\end{array}$} & Neme & Nincs szignifikáns hatás & Nincs szignifikáns hatás \\
\hline & Életkora & Nincs szignifikáns hatás & Nincs szignifikáns hatás \\
\hline \multirow[t]{2}{*}{$\begin{array}{l}\text { Idő és } \\
\text { a távolság } \\
\text { hatása }\end{array}$} & $\begin{array}{l}\text { Különélés } \\
\text { ideje }\end{array}$ & & $\begin{array}{l}\text { Van szignifikáns hatás: minél } \\
\text { régebb óta nem él együtt az apa } \\
\text { a gyermekével, annál ritkábban } \\
\text { találkoznak }\end{array}$ \\
\hline & $\begin{array}{l}\text { Távolság (egy } \\
\text { településen } \\
\text { lakik-e a } \\
\text { külön élö apa } \\
\text { és a gyermek) }\end{array}$ & & $\begin{array}{l}\text { Van szignifikáns hatás: ha azonos } \\
\text { településen lakik az apa és } \\
\text { a külön élő gyermeke, akkor } \\
\text { többször találkoznak }\end{array}$ \\
\hline
\end{tabular}

(Életünk fordulópontjai adatbázis 4 . hullám, $\mathrm{N}=165$ )

nifikánsan ritkábban találkoznak a külön élő gyermekeikkel. A többi változónak nem volt szignifikáns hatása, amely az alacsony elemszámmal is magyarázható. A második modellben kontrolláltunk a szociodemográfiai változókra, és bevontuk a különélés idejét, és hogy vajon azonos településen él-e a külön élő apa és a gyermeke. Ekkor az apa jelenlegi családi állapotának megszünt a szignifikáns hatása, viszont mindkét új változónk hatása szignifikánsnak bizonyult. Azaz mi- 
nél régebb óta nem él együtt az apa a gyermekével, annál ritkábban találkoznak; és ha azonos településen lakik az apa és a külön élő gyermeke, akkor többször találkoznak, mint abban az esetben, ha különbözö településen élnek.

Azt is megvizsgáltuk, hogy a külön élő gyermek szokott-e a külön élő apánál aludni. Ennek a vizsgálata azért fontos, mert így a kapcsolattartás intenzívebb formáját is tudjuk mérni. Az apák az esetek 57\%-ban számoltak be arról, hogy előfordul, hogy a külön élő gyermek nála alszik. Az ottalvás szorosan összefügg a találkozások gyakoriságával. Azoknak az apáknak, akik hetente többször vagy akár mindennap személyesen találkoznak a külön élő gyermekeikkel, a 80\%-a számolt be arról, hogy szokott náluk aludni a külön élő gyermekük. Nem találtunk kapcsolatot a gyermek neme és az életkora, valamint a között, hogy a gyermek szokott-e a külön élő apánál aludni - bár ez az alacsony elemszám miatt is előfordulhat.

\section{A kvalitatív vizsgálat eredményei}

A kvalitatív elemzés a mechanizmusok mélyebb megértését teszi lehetővé. A huszonöt interjú alapján is az rajzolódott ki, hogy a kapcsolattartást nagyon erősen befolyásolja a külön élő apa és a gyermeke közötti távolság: amennyiben távol élnek egymástól, általában a találkozások is ritkábbak. Ez az eredmény megegyezik a kvantitatív elemzésünk eredményeivel. Ahogy ezt feltételeztük, a nem azonos településen élés negatív hatása nagy részben annak tudható be, hogy az ilyen találkozások nagyobb anyagi ráfordítást igényelnek.

Az érettségivel rendelkező, vidéken élő Dániel (40 éves, müszakvezető) arról számolt be, hogy míg a fia kisebb volt, a találkozások számát erősen befolyásolta a távolság és az azzal járó útiköltség: „Nagyon drága volt ugye, hogy autóval felmenni érte mindig, lehozni, aztán visszahozni.” A gyermek anyjával kötött megállapodása szerint a fiú az általános iskolai ballagása után egyedül is meglátogathatta apját, amiről Dániel pozitívan nyilatkozik: „Mióta vonattal jár, az nekem sokkal könnyebb, mert így kifizetek neki kb. $1400 \mathrm{Ft}$-ot a jegyre, amikor meg még kocsival mentem, akkor fizettem olyan 12 ezer Ft-ot benzinre."

A magas iskolai végzettségü, fővárosban élő Kornél (45 éves informatikus) is távol lakik a kiskorú lányától. Kornél és kislánya rendszeres találkozását az segíti elő Kornél beszámolója szerint, hogy a gyermeket felváltva viszi hozzá volt felesége és annak új férje, és ő maga is szokott a kislányért menni. Ebben azért állapodtak meg így, hogy ne az apára háruljon az utazási költségek egésze, valamint, hogy az utazással járó nehézségek ne álljanak útjában a rendszeres találkozásoknak.

A másik összefüggés, amely kirajzolódott az interjúk elemzése során, az volt, hogy a gyermek életkora szerint változik a külön élő szülővel való kapcsolattartás. Ez látszólag ellentmond a kvantitatív elemzésből származó eredményeknek, ahol 
nem találtunk szignifikáns összefüggést a gyermek életkora és a külön élő szülővel történő kapcsolattartás között. Ez az ellentmondás azért látszólagos, mert az adatbázisunk alacsony elemszáma nem tette lehetővé, hogy korcsoportokra bontva vizsgáljuk a gyermek életkorának hatását a kapcsolattartásra. Az interjúk elemzése azonban rávilágított arra, hogy a találkozások száma és a gyermekek életkora közötti kapcsolatban két mintázat figyelhető meg.

Egyrészt megfigyelhető a korábbi tanulmányok által is bemutatott jelenség, azaz, hogy az apák inkább tartják a kapcsolatot az idősebb gyermekeikkel. A kisgyerektől külön élő apák legtöbbször azt tapasztalják, hogy az anya korlátozza a kapcsolattartást. E mögött általában az áll, hogy az anyák úgy érzik, az apák nem tudnak megfelelően gondoskodni egy kisgyermekről. A közepes iskolai végzettségű, fôvárosban élő Tamásnál (39 éves, ingatlanközvetítő) például óvodáskoráig nem aludt ott a gyermeke. Erről így számol be: „Hétvégén meg egy napot áldoztam rá. Igaz nem aludt nálam, de hoztam, majd visszavittem. Aztán utána óvodáskorában aludt nálam." Ezt ő maga is természetesnek véli, mert azt gondolja, hogy egy kisgyerekről az anya tud csak jól gondoskodni. Ebben az esetben Tamás volt párja is így vélekedett, és az ő beszámolója szerint is négy-öt éves lehetett a kisfia, amikor először az apjánál aludhatott.

A főiskolai végzettségü, falun élő Eriknél (37 éves, munkaügyi ellenőr) a gyermek négy hónapos volt, amikor a szülök párkapcsolata felbomlott. Erik költözött ki a házból, ahol a volt párjával és annak szüleivel élt korábban. Bár Eriknek rendkívül rossz érzés volt visszamenni abba a házba, de az anya (Erika) ragaszkodott ahhoz, hogy csak és kizárólag náluk találkozhat a gyerekével: „Abban állapodtunk meg, hogy az egyik héten úgy láthatja, hogy szerdán délután 5-töl 7-ig, következő héten meg szombaton reggeltől altatás időszakig, utána visszajöhet, amikor fölkel, akkor megint estig, de mindezt nálunk" (Erika, 28 éves, fodrász). Az anya attól is teljes mértékben elzárkózott, hogy házon kívülre vigye az apa a gyereket, amit azzal indokolt, hogy egy pár hónapos gyereknek nem jó, ha idegen helyen tartózkodik az apa kényelmének érdekében. Náluk is a gyermek óvodáskora körül történt változás a kapcsolattartásban. Erik ekkortól elvihette a gyermeket a saját házába több órára is, azonban éjszakára még nem aludhatott ott. Ezt Erik is elfogadja, hiszen a gyermeke nagyon ragaszkodik az anyjához, viszont várja már a következő a nyarat, amikor abban bízik, hogy már éjszaka is nála aludhat a lánya.

A másik mintázat pedig az, hogy kamaszkorú gyermekek esetében csökken a találkozások száma. Ez annak tudható be, hogy felértékelődik a kortárs csoporttal töltött idő, amit legtöbbször nem is sérelmeztek az apukák. A városban élö, diplomával rendelkező Barnabás (45 éves, vállalkozó) például aktív lépéseket tesz annak érdekében, hogy „,versenyképes” maradjon a kortárs csoporttal. Erről így számol be: „Most ezek úgy érzem, hogy nekem lettek fontosabbak [a találkozások], így most ezt nekem kell életben tartanom: kitalálni olyan programokat, ami 
számukra érdekes, felhívni őket stb. De egyelőre nehéz vetélkedni a saját baráti körükkel, most, hogy kamaszok lettek, ez sokszor nem is sikerül. Ez a kéthetente találkozunk ütem ez teljesen meg is szünt.” A fővárosban élö, magas iskolai végzettségủ Fülöp (49 éves, bankár) kamaszkorú gyermekei is egyre több időt szenteltek a baráti kapcsolatoknak, de ezzel Fülöp nem is akart versenyezni: „Én mindig propagáltam, tehát ha olyan ütközés merült fel időben, hogy most életkori társaságba menjenek vagy hozzám jöjjenek, akkor én a legtöbbször biztattam őket, hogy az életkori társasággal tartsák a kapcsolatot. Tehát, hogy az szerintem fontosabb, mint a távollévő szülővel való kapcsolat.” Dániel (40 éves, müszakvezető) pedig azzal próbálta elősegíteni a kamasz fiával való kapcsolattartást, aki egy másik városban élt, hogy meghívta hozzájuk az iskolai szünetben nemcsak a kamasz fiát, hanem annak legjobb barátját is.

Összegezve: az interjúkból az derül ki, hogy a legrendszeresebb kapcsolattartás az óvodás- és kamaszkor közötti időszakban alakul ki a gyermek és a külön élő szülő között, amit több apa maga is megfigyelt. A gyermekekkel együtt élő szülők (általában anyák) is ebben az időszakban támogatják leginkább a kapcsolatot a gyermek és a külön élő apák között. Ennek hátterében az is állhat, hogy a gyermek életkorának növekedésével csökken az a társadalmi nyomás az anyákon, amely azt írja elő számukra, hogy nekik kell betölteni a kizárólagos gondozói szerepet.

\section{ÖSSZEFOGLALÁS}

Jelen tanulmány célja az volt, hogy betekintést nyújtson abba, hogy ma Magyarországon a külön élő apák hogyan tartják a kapcsolatot gyermekeikkel. Bár egy külön élő apa sokféle módon részt vehet a gyermeke életében, mint például anyagi és/vagy érzelmi támogatás nyújtásával, a gyermek életét érintő fontos döntések meghozásában való részvétellel, mi csak egy szük területet vizsgáltunk: mi befolyásolja a külön élö apa és gyermek között a személyes találkozások gyakoriságát.

A kvantitatív adatok - bár rendkívül alacsony elemszámú minta állt csak rendelkezésünkre - azt mutatták, hogy az apa új családi állapota befolyásolhatja a találkozások számát. Azok az apák, akik új párkapcsolatot alakítottak ki, és háztartásukban kiskorú gyermeket is nevelnek, ritkábban találkoznak a külön élő gyermekeikkel, mint azok a társaik, akik nem létesítettek új párkapcsolatot. Ezenkívül annak is volt szerepe, hogy a külön élő apa azonos településen él-e a gyermekével, ha igen, akkor gyakoribb volt a találkozások száma. Továbbá az is kiderült, hogy az apa minél régebb óta nem él együtt a gyermekével, annál ritkábban találkoznak.

A kvalitatív adatok részben hasonló eredményeket hoztak: megerősítették, hogy ha az apa és a külön élő gyermek messze lakik egymástól, akkor ritkábban találkoznak, mivel nagyobb anyagi és időbeli ráfordítást igényelnek ezek a 
találkozások. Az interjúk elemzése alapján arra is fény derült, hogy a gyermek életkora fontos a találkozások számának alakulása szempontjából: az apák legintenzívebben az óvodás- és kamaszkor között tartják a kapcsolatot gyermekeikkel. Ennek az összefüggésnek az állhat a hátterében, hogy a három év alatti gyermekeket az anyák nem szívesen bízzák az apákra, valamint maguk az apák is úgy gondolják, hogy jobb a gyermeknek az anya mellett. Miközben a kamaszkorú gyermekek azért találkoznak ritkábban a külön élő szülővel, mert kortársaik társaságát preferálják a szülővel való kapcsolattartás helyett.

A tanulmány a Bolyai János Kutatási Ösztöndíj támogatásával, valamint az Innovációs és Technológiai Minisztérium ÚNKP-19-4-BCE-11 kódszámú Új Nemzeti Kiválóság programjának szakmai támogatásával készült.

\section{IRODALOM}

Cheadle, J. E. - Amato, P. R. - King, V. (2010): Patterns of Nonresident Father Contact. Demography, 47, 1, 205-225. DOI: 10.1353/dem.0.0084, https://europepmc.org/article/pmc/ pmc2858317

Goldberg, J. S. (2015): Coparenting and Nonresident Fathers' Monetary Contributions to Their Children. Journal of Marriage and the Family, 77, 3, 612-627. DOI: 10.1111/jomf.12191, https:// www.ncbi.nlm.nih.gov/pmc/articles/PMC4452134/

Goldberg, J. S. - Carlson, M. J. (2015): Patterns and Predictors Of Coparenting After Unmarried Parents Part. Journal of Family Psychology, 29, 3, 416-426. DOI: 10.1037/fam0000078, https:// www.ncbi.nlm.nih.gov/pmc/articles/PMC6057872/

Lindberg, L. D. - Kost, K. - Maddow-Zimet, I. (2017): The Role of Men's Childbearing Intentions in Father Involvement. Family Relations, 79, 1, 44-59. DOI: 10.1111/jomf.12377/jomf.12377, https://onlinelibrary.wiley.com/doi/full/10.1111/jomf.12377

Makay Zs. - Spéder Zs. (2018): Apaság: a férfiak gyermekvállalása és családi szerepei. In: Monostori J. - Öri P. - Spéder Zs. (szerk.): Demográfiai Portré 2018. Jelentés a magyar népesség helyzetéröl. Budapest: KSH Népességtudományi Kutatóintézet, 65-82. https://demografia.hu/ kiadvanyokonline/index.php/demografiaiportre/article/view/2731/2644

Manning, W. D. - Stewart, S. D. - Smock, P. J. (2003): The Complexity of Fathers' Parenting Responsibilities and Involvement with Nonresident Children. Journal of Family Issues, 24, 5, 645-667. DOI: 10.1177/0192513X03252573, https://www.researchgate.net/publication/242213560_The_Complexity_of_Fathers'_Parenting_Responsibilities_and_Involvement_with_Nonresident_Children

Maslauskaitè, A. - Tereškinas, A. (2020): Quality of Non-resident Father-Child Relationships: Between "Caring for" and "Caring About". In: Mortelmans D. (ed.): Divorce in Europe. New Insights in Trends, Causes and Consequences of Relation Break-ups. Antwerp: Springer, 291-315. DOI: 10.1007/978-3-030-25838-2_14, https://link.springer.com/chapter/10.1007/978-3-030-25838-2_14

Meggiolaro, S. - Ongaro, F. (2015): Non-resident Parent-Child Contact after Marital Dissolution and Parental Repartnering: Evidence from Italy. Demographic Research, 33, 40, 1138-1148. DOI: 10.4054/DemRes.2015.33.40, https://www.demographic-research.org/volumes/vol33/40/33-40.pdf 
Murinkó L. - Szalma I. (2016): Fatherhood and Men's Second Union Formation: Norway, France, and Hungary, 1980-2000. In: Mortelmans, D. - Matthijs, K. - Alof, E. et al. (eds.): Changing Family Dynamics and Demographic Evolution: The Family Kaleidoscope. Cheltenham: Elgar, 179-213. https://www.researchgate.net/publication/305210348_Fatherhood_and_men's_second_union_formation_Norway_France_and_Hungary_1980s-2000s

Seltzer, J. A. (1991): Relationships between Fathers and Children Who Live Apart: The Father's Role after Separation. Journal of Marriage and Family, 53, 1, 79-101. DOI: 10.2307/353135

Skevik, A. G. (2006): Absent Fathers or Reorganized Families? Variations in Father-Child Contact after Parental Break-up in Norway. Sociological Review, 54, 1, 114-132. DOI: 10.1111/j.1467954X.2006.00604.X

Spéder Zs. (2011): Ellentmondó elvárások között... Családi férfiszerepek, apaképek a mai Magyarországon. In: Pongrácz T-né (szerk.): A családi értékek és a demográfiai magatartás változásai. (KSH Népességtudományi Kutatóintézetének Kutatási Jelentései 91) Budapest: KSH, 129-149. http://demografia.hu/hu/letoltes/kiadvanyok/Szerepvaltozasok/207-228Speder.pdf

Szalma I. - Rékai K. (2019): Szülöi felügyeleti jog, kapcsolattartás és tartásdíjfizetés a külön élő magyar szülők gyakorlatában. Szociológiai Szemle, 4, 84-114. http://real.mtak. hu/107507/1/83_114_oldal_JAV04.pdf 